\title{
Anmeldelser
}

Tips om medisinsk litteratur, andre bøker, filmer og elektroniske medier som bør anmeldes, sendes tidsskriftet@legeforeningen.no

\section{Sunn av det skjønne, syk av det stygge?}

Caspari S

Estetikk og helse

137 s, ill. Oslo: Cappelen Damm, 2009.

Pris NOK 249

ISBN 978-82-02-30678-6

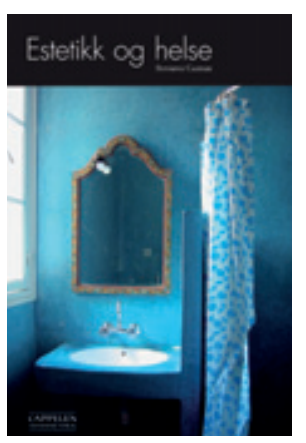

Er det bra for oss at vi har det pent rundt oss? Og er det i så fall bra for vår helsetilstand? Forfatteren av denne boken er cand.philol. fra Universitetet i Oslo, med grunnfag i pedagogikk, mellomfag i idéhistorie og hovedfag i filosofi. I tillegg er hun sykepleier, har undervisningserfaring og forskningsbakgrunn fra Høgskolen i Oslo og er aktiv billedkunstner. Hun har skrevet en doktorgradsavhandling med tittelen Det gyldne snitt - Den estetiske dimensjon, en kilde til helse og et etisk anliggende (1). Hennes bakgrunn for å drøfte sammenhengen mellom estetikk og helse burde derfor være uslåelig.

Emnet for den foreliggende boken er vidt, men forfatteren konsentrerer seg om miljøet i helseinstitusjoner. Hennes konklusjon, sammenfattet i siste avsnitt (s. 123), er kanskje ikke overraskende: «Skjønnhet alene kan kanskje ikke helbrede, men skjønnhet og estetikk er en viktig dimensjon både når det gjelder å bevare og å gjenopprette helsen samt for å ivareta menneskets verdighet $\mathrm{i}$ dagliglivet, $\mathrm{i}$ institusjoner ved sykdom og rehabilitering, samt i livets siste fase.» Altså et klart tja til spørsmålet om estetikken virker. De enkelte kapitlene fører fra hver sin synsvinkel frem til denne konklusjonen.

Boken er populærvitenskapelig. Den er normativ i den forstand at de litteraturbelagte drøftingene fører frem til anbefalinger for et estetisk miljø, slik forfatteren mener det bør være for å være helsemessig gunstig. Som et vedlegg refererer hun «vårdvitenskapens grunnantagelser» (vedlegg 3, s. 129). Dette understreker at forfatteren har et normativt budskap.

Fremstillingsformen blir av og til litt utflytende, og fagspråket kan under tiden virke fremmed for den allmenne leser.
For eksempel definerer hun «vård» brukt som et norsk ord og redegjør for dets betydning (s. 128), men likevel skurrer det mange av de gangene begrepet opptrer i teksten.

Boken gir mersmak, og siden det i forordet står at den bygger på doktoravhandlingen, fikk jeg fatt i denne. Faktisk viste den 263 sider tykke avhandlingen seg å være enda mer interessant å lese. I denne beskriver hun nemlig sitt omfattende empiriske arbeid om estetikk i helseinstitusjoner. Gjennom flere delstudier har hun tatt for seg problemstillingene på flere måter. Disse håndfaste erfaringene får bare en beskjeden plass i den nye boken. Det er synd, fordi de er viktige premisser for hennes synspunkter på estetikkens plass i helsearbeidet.

\section{Øivind Larsen}

Institutt for allmenn- og samfunnsmedisin Universitetet i Oslo

\section{Litteratur}

1. Caspari S. Det gyldne snitt - Den estetiske dimensjon, en kilde til helse og et etisk anliggende. Doktoravhandling. Åbo: Samhälls- och vårdvetenskapliga fakulteten, Åbo Akademi, 2004.

\section{Storm i forskningsetisk vannglass}

Ruyter KW, Solbakk JH, Waal H, red Rusmiddelbrukeren og forskeren 148 s, tab. Oslo: Senter for rus- og avhengighetsforskning, 2009. Pris gratis ISBN 978-82-303-1257-5

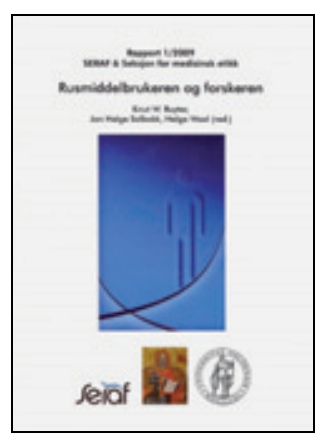

2. juni 2008 publiserte Apollon, Universitetet i Oslos prisbelønte forskningsmagasin, en rekke innslag om rusforskning. Et av innslagene, Rusavhengige deltar i forskning med livet som innsats, var et intervju med allmennlege Jo Siri Ekgren, som hadde sendt bekymringsmeldinger til Helsetilsynet, Regional etisk komité og Det medisinske fakultet ved Universitetet i Oslo der han beskyldte forskerne bak flere placebokontrollerte forsøk med substitusjonspreparatene Metadon og Subutex for uetisk virksomhet. Samme dag, og sikkert ikke tilfeldig, var det et innslag i NRKs forskningsmagasin Verdt å vite, der Ekgren, godt sekundert av etikkprofessor Jan Helge Solbakk, fikk fremføre sine beskyldninger som professor Helge Waal, hovedmannen bak de omtalte forsøkene, måtte stå til rette for. Felles for disse to medieoppslagene var at journalistene (og Solbakk) valgte Ekgrens forskningsfiendtlige posisjon. Dette ga gjenklang i journalistlauget, og flere medier kastet seg raskt på karusellen i håp om å gjøre et skup. Dagens medisin hadde selvsagt et oppslag, og Morgenbladet hadde en meget forskningskritisk lederkommentar, med påfølgende «brannslukking» fra professor Waal og dekanus Wisløff. Men det var særlig den erfarne Aftenposten-journalisten Per Kristian Aale som holdt det gående utover sommeren, bl.a. med assistanse fra Solbakk og menneskerettighetsekspert Gro Hillestad Thune, som begge selvsagt bare uttalte seg «på generelt grunnlag». Etter hvert som temperaturen steg tok professor Waal tyren ved hornene ved å foreslå at partene kunne møtes til intellektuell holmgang på seminaret Rusmiddelbrukere og forskeren, 2 . og 3 . oktober 2008.

Det lille heftet Tidsskriftet har bedt meg om å omtale, er innleggene fra dette seminaret: Sårbare grupper - forskningsetiske retningslinjer og prinsipper. Heftet har et felles forord av professorene Knut W. Ruyter, Den nasjonale forskningsetiske komité for medisin og helsefag, Jan Helge Solbakk, Seksjon for medisinsk etikk, Universitetet i Oslo, og Helge Waal, Senter for rus- og avhengighetsforskning, Universitetet i Oslo.

Seminaret ble en kombinasjon av et oppgjør med og en avrunding av den heftige mediediskusjonen som Ekgren, godt hjulpet av skupsøkende journalister, hadde startet på forsommeren. For den som ønsker å se professor Solbakk legge seg flat, kan kapitlet Noen (selv)kritiske refleksjoner, observasjoner og spørsmål anbefales. I tillegg er det en del bestilte innlegg fra andre forskere, som f.eks. Hvem tilhører en «sårbar gruppe» - og er det alltid beskyttelse de (vi) trenger? (Beate Indrebø Hovland, Lovisenberg diakonale høgskole), eller Når er et samtykke til rusavhengige personer etisk og juridisk bindende (Olav Gjelsvik og Edmund Henden, Institutt for filosofi, idé- og kunsthistorie og klassiske språk, Universitetet i Oslo). Kvaliteten på innleggene er svært varierende, til dels 